\title{
Effect of Different Concentration of N, P and $K$ on Yield at Capsicum (Capsicum annum L. Var. grossum) in Soilless Media
}

\author{
Mashetty Rakesh Kumar* and Vijay Bahadur
}

Department of Horticulture, Sam Higginbottom University of Agriculture, Technology and Sciences, Prayagraj (U.P), India

*Corresponding author

\begin{abstract}
A B S T R A C T
Keywords

Capsicum, Different concentrations of NPK, Yield parameters and Soilless growing media

Article Info

Accepted:

04 October 2020

Available Online:

10 November 2020

The present experiment was carried out during November, 2019 to April, 2020 in Shade net, Research Field, Department of Horticulture, SHUATS, Prayagraj. The experiment was conducted in Randomized Block Design (RBD), with eight treatments, replicated thrice with growing media (FYM + Vermicompost + Cocopeat) and variety (Ganga) on Capsicum. The treatments were $\mathrm{T}_{1}(\mathrm{NPK} 5 \mathrm{ml}), \mathrm{T}_{2}(\mathrm{NPK} 10 \mathrm{ml}), \mathrm{T}_{3}(\mathrm{NPK} 15.5 \mathrm{ml}), \mathrm{T}_{4}$ (NPK $20 \mathrm{ml}), \mathrm{T}_{5}(\mathrm{NPK} 24.5 \mathrm{ml}), \mathrm{T}_{6}(\mathrm{NPK} 28.50 \mathrm{ml}), \mathrm{T}_{7}(\mathrm{NPK} 32.50 \mathrm{ml})$ and $\mathrm{T}_{8}$ or $\mathrm{T}_{0}(\mathrm{NPK} 0 \mathrm{ml})$. From the present experimental findings in terms of yield parameters treatment $T_{5}$ was superior followed by $T_{3}$ and $T_{7}$.
\end{abstract}

\section{Introduction}

Vegetables are rich and comparatively cheaper source of vitamins. The importance of vegetable crops in India can be judged from the fact that the majority of Indian population is vegetarian. India produces the largest variety of vegetables. Consumption of vegetable provides taste, palatability, increases appetite and provides fiber for digestion and prevents constipation.

Capsicum (Capsicum annuum L. var. grossum) is also known as bell pepper or sweet pepper and is one of the most popular and highly remunerative annual herbaceous vegetable crops particularly for protected cultivation. Sweet pepper (Capsicum annuиm L. var. Grossum) belongs to the family solanaceae and it is different from chilli (Capsicum annuum L.var. grossum). It is also called by other names such as shim lamirch, green pepper and capsicum.

Capsicum is cultivated in most parts of the world, especially in temperate regions of Central and South America and European countries, tropical and subtropical regions of 
Asian continent mainly in India and China. In India, capsicum is extensively cultivated in Andhra Pradesh, Karnataka, Maharashtra, Tamilnadu, Himachal Pradesh, and hilly areas of Uttar Pradesh (Sreedhara et al., 2013). In India, capsicum is grown for its mature fruits and is widely used in stuffing and baking. It is also used in salad, noodles and soup preparation. It is a very rich source of vitamins $\mathrm{A}$ and $\mathrm{C}$ (ascorbic acid). It has been found that every 100 grams of edible portion of capsicum provides $24 \mathrm{kcal}$ of energy, gram of protein, 4.3 gram of carbohydrate and 0.3 gram of fat (Anon., 2010).

Water and nutrient management through drip fertigation in soilless media improves water, nutrient and air distribution in the growing medium and subsequently improves crop health and productivity. Drip fertigation in soilless cultivations used to supply complete nutrient solution with irrigation water. Fertigation scheduling is the process of determining how much water and nutrient solution to apply by fertigation volume and timing. The main goal of water and nutrient management for greenhouse soilless crops is to enhance crop growth and product quality and simultaneously reduce losses of water and nutrients to the environment. Precise amount of water and nutrients as per crop demand in different stages through drip fertigation is important to reach this goal. In order to do so, quantitative information on demand and uptake of water and nutrients and related information on crop behavior is required.

\section{Materials and Methods}

The present Experiment was conducted in Randomized Block Design (RBD), with eight treatments, replicated thrice with growing media (FYM + Vermicompost + Cocopeat) and capsicum variety (Ganga), in the Shade net, Research field, Department of Horticulture, Sam Higginbottom University of
Agriculture, Technology and Sciences, Prayagraj during November, 2019 to April, 2020. Total number of treatments were eight viz. $\mathrm{T}_{1}(\mathrm{NPK} 5 \mathrm{ml}), \mathrm{T}_{2}(\mathrm{NPK} 10 \mathrm{ml}), \mathrm{T}_{3}(\mathrm{NPK}$ $15.5 \mathrm{ml}), \mathrm{T}_{4}(\mathrm{NPK} 20 \mathrm{ml}), \mathrm{T}_{5}(\mathrm{NPK} 24.5 \mathrm{ml})$, $\mathrm{T}_{6}(\mathrm{NPK} 28.50 \mathrm{ml}), \mathrm{T}_{7}(\mathrm{NPK} 32.50 \mathrm{ml})$ and $\mathrm{T}_{8}$ or $\mathrm{T}_{0}(\mathrm{NPK} 0 \mathrm{ml})$.

\section{Climatic condition in the experimental site}

The area of Prayagraj district comes under subtropical belt in the south east of Utter Pradesh, which experience extremely hot summer and fairly cold winter. The maximum temperature of the location reaches up to $46^{\circ}$ $\mathrm{C}-48^{\circ} \mathrm{C}$ and seldom falls as low as $4^{\circ} \mathrm{C}-5^{\circ} \mathrm{C}$. The relative humidity ranges between 20 to $94 \%$. The average rainfall in this area is around $1013.4 \mathrm{~mm}$ annually. However, occasional precipitation is also not uncommon during winter months.

\section{Results and Discussion}

The present investigation entitled "Effect of different concentration of $\mathrm{N}, \mathrm{P}$ and $\mathrm{K}$ on growth, yield and quality at Capsicum (Capsicum annum L. Var. grossum) in soilless media" was carried out during November, 2019 to April, 2020 in Shade net, Research Field, Department of Horticulture, Naini Agricultural Institute, Sam Higginbottom University of Agriculture, Technology and Sciences, Prayagraj (U.P.) India.

The results of the present investigation, regarding the effect of different concentration of NPK on growth, yield and quality of Capsicum (Capsicum annum L. Var. grossum), have been discussed and interpreted in the light of previous research work done in India and abroad. The experiment was conducted in Randomized block design with 8 treatments, and three replications. 
The results of the experiment are summarized below.

\section{Yield Parameters}

In terms of Fruit set/cluster and Number of fruits/plant for different treatment combinations Statistically significant variation was recorded maximum Fruit set/cluster and Number of fruit/plant (3.77 and 4.65 respectively) was recorded in treatment $\mathrm{T}_{5}$ (NPK $24.5 \mathrm{ml}$ ), followed by $\mathrm{T}_{3}$ (NPK $15.5 \mathrm{ml}$ ) with $(3.21$ and 4.40 respectively), whereas minimum Fruit set/cluster and Number of fruit/plant (2.34 and 3.29 respectively), was observed in treatment $\mathrm{T}_{1}(\mathrm{NPK} 5 \mathrm{ml})$. Fruit yield/plant and per 100 sq. meter for different treatment combinations maximum fruit yield $(1250.32 \mathrm{~g}$ and $551.38 \mathrm{~kg}$ respectively) was recorded in treatment $\mathrm{T}_{5}$ (NPK $24.5 \mathrm{ml}$ ), followed by $\mathrm{T}_{3}$ (NPK $15.5 \mathrm{ml}$ ) with $(995.51 \mathrm{~g}$ and $438.98 \mathrm{~kg}$ ), whereas minimum fruit yield per plant and per 100 sq. meter $(644.11 \mathrm{~g}$ and $284.05 \mathrm{~kg}$ ), was observed in treatment $\mathrm{T}_{1}(\mathrm{NPK} 5 \mathrm{ml})$. This might be attributed to enhanced photosynthesis, accumulation of carbohydrates and favorable effect on vegetative growth which increased the fruit set per plant and also increases the weight and size of fruit. This finding correlates the findings of Della coasta, L. and Gianquinto, G.,(2002), Schnitzler et al., (2004), Khan et al., (2010), Fatma Gungor and Ertan Yildirim (2013), Mohammed Dahiru Toungos (2017) and Ngupok et al., (2018) in Capsicum.

Effect of different concentration of $N, P$ and $K$ on No. of Flower cluster/plant, No. of Flower/cluster and Fruit set/cluster of Capsicum in Soilless media

The data on Number of flower cluster/plant after application of NPK in different treatment combinations was recorded and are presented in table 1. Critical analysis of data displayed in table clearly marked out the obvious difference among the treatments with respect to Number of flower cluster/plant. Statistically significant variation was recorded for Number of flower cluster/plant for different treatment combination of NPK. Maximum Number of flower cluster/plant (3.80) was recorded in treatment $\mathrm{T}_{5}$ (NPK $24.5 \mathrm{ml}$ ), followed by $\mathrm{T}_{7}$ (NPK $32.5 \mathrm{ml}$ ) with (3.43), whereas minimum number of flower cluster/plant (2.21), was observed in treatment $\mathrm{T}_{1}$ (NPK $5 \mathrm{ml}$ ). This might be due to enhanced photosynthetic and other metabolic activities which lead to increase in various plant metabolites responsible for cell division and elongation. This finding correlates the findings of Ngupok et al., (2018) in Capsicum.

The data on Number of flower/cluster after application of NPK in different treatment combinations was recorded and are presented in table 2. Critical analysis of data displayed in table clearly marked out the obvious difference among the treatments with respect to Number of flower/cluster. Statistically significant variation was recorded for Number of flower/cluster for different treatment combination of NPK. Maximum Number of flower/cluster (8.67) was recorded in treatment $\mathrm{T}_{5}$ (NPK $24.5 \mathrm{ml}$ ), followed by $\mathrm{T}_{7}$ (NPK $32.5 \mathrm{ml}$ ) with (8.34), whereas minimum number of flower/cluster (5.66), was observed in treatment $\mathrm{T}_{1}$ (NPK $5 \mathrm{ml}$ ). This might be due to enhanced photosynthetic and other metabolic activities which lead to increase in various plant metabolites responsible for cell division and elongation. This finding correlates the findings of Ngupok et al., (2018) in Capsicum.

The data on Fruit set/cluster after application of NPK in different treatment combinations was recorded and are presented in table 2 . Critical analysis of data displayed in table clearly marked out the obvious difference 
among the treatments with respect to Fruit set/cluster. Statistically significant variation was recorded for Fruit set/cluster for different treatment combination of NPK. Maximum Fruit set/cluster (3.77) was recorded in treatment $\mathrm{T}_{5}$ (NPK $24.5 \mathrm{ml}$ ), followed by $\mathrm{T}_{3}$ (NPK $15.5 \mathrm{ml}$ ) with (3.21), whereas minimum Fruit set/cluster (2.34), was observed in treatment $\mathrm{T}_{1}$ (NPK $5 \mathrm{ml}$ ). This might be attributed to enhanced photosynthesis, accumulation of carbohydrates and favourable effect on vegetative growth which increased the fruit set per cluster and also increases the weight and size of fruit. This finding correlates the findings of Ngupok et al., (2018) in Capsicum.

Table.1 Effect of different concentration of N, P and K on No. of Flower cluster/plant, No. of Flower/cluster and Fruit set/cluster of Capsicum in Soilless media

\begin{tabular}{|c|c|c|c|c|}
\hline Treatment & $\begin{array}{c}\text { Treatment } \\
\text { Combination }\end{array}$ & $\begin{array}{c}\text { No. of Flower } \\
\text { cluster/plant }\end{array}$ & $\begin{array}{c}\text { No. of } \\
\text { Flower/cluster }\end{array}$ & $\begin{array}{c}\text { Fruit } \\
\text { set/cluster }\end{array}$ \\
\hline $\mathbf{T}_{\mathbf{1}}$ & NPK@ 5 ml/L & 2.21 & 5.66 & 2.34 \\
\hline $\mathbf{T}_{\mathbf{2}}$ & NPK @ 10 ml/L & 2.42 & 7.21 & 2.51 \\
\hline $\mathbf{T}_{\mathbf{3}}$ & NPK @ 15.5 ml/L & 3.39 & 8.10 & 3.21 \\
\hline $\mathbf{T}_{\mathbf{4}}$ & NPK@ $20 \mathrm{ml} / \mathrm{L}$ & 2.45 & 8.00 & 2.93 \\
\hline $\mathbf{T}_{\mathbf{5}}$ & NPK @ 24.5 ml/L & 3.80 & 8.67 & 3.77 \\
\hline $\mathbf{T}_{\mathbf{6}}$ & NPK @ 28.5 ml/L & 2.88 & 6.89 & 3.00 \\
\hline $\mathbf{T}_{\mathbf{7}}$ & NPK @ 32.5 ml/L & 3.43 & 8.34 & 3.14 \\
\hline $\mathbf{T}_{\mathbf{0}}$ & NPK @ 0 ml/L & 0.00 & 0.00 & 0.00 \\
\hline & F-Test & S & S & S \\
\hline & SE(d) & 0.166 & 0.230 & 0.156 \\
\hline & C.V. & 7.882 & 4.270 & 7.309 \\
\hline & C.D. at 5\% & 0.359 & 0.499 & 0.338 \\
\hline
\end{tabular}

Table.2 Effect of different concentration of N, P and K on Number of Fruits/ Plant, Avg. Fruit Weight and Fruit Yield/Plant of Capsicum in Soilless media

\begin{tabular}{|c|c|c|c|c|}
\hline Treatment & Treatment Combination & $\begin{array}{c}\text { No. of Fruits/ } \\
\text { Plant }\end{array}$ & $\begin{array}{c}\text { Avg. Fruit } \\
\text { Weight (g) }\end{array}$ & $\begin{array}{c}\text { Fruit } \\
\text { Yield/Plant (g) }\end{array}$ \\
\hline $\mathbf{T}_{\mathbf{1}}$ & NPK@ 5 ml/L & 3.29 & 196.20 & 644.11 \\
\hline $\mathbf{T}_{\mathbf{2}}$ & NPK @ $10 \mathrm{ml} / \mathrm{L}$ & 3.73 & 198.95 & 740.38 \\
\hline $\mathbf{T}_{\mathbf{3}}$ & NPK @ $15.5 \mathrm{ml} / \mathrm{L}$ & 4.40 & 226.45 & 995.51 \\
\hline $\mathbf{T}_{\mathbf{4}}$ & NPK@ $20 \mathrm{ml} / \mathrm{L}$ & 3.78 & 201.09 & 757.98 \\
\hline $\mathbf{T}_{\mathbf{5}}$ & NPK @ $24.5 \mathrm{ml} / \mathrm{L}$ & 4.65 & 269.30 & $1,250.32$ \\
\hline $\mathbf{T}_{\mathbf{6}}$ & NPK @ $28.5 \mathrm{ml} / \mathrm{L}$ & 3.81 & 203.69 & 777.71 \\
\hline $\mathbf{T}_{\mathbf{7}}$ & NPK @ 32.5 ml/L & 4.16 & 213.66 & 887.84 \\
\hline $\mathbf{T}_{\mathbf{0}}$ & NPK @0 ml/L & 0.00 & 0.00 & 0.00 \\
\hline & F-Test & $\mathrm{S}$ & $\mathrm{S}$ & $\mathrm{S}$ \\
\hline & SE(d) & 0.217 & 11.024 & 62.224 \\
\hline & C.V. & 7.637 & 7.157 & 10.071 \\
\hline & C.D. at 5\% & 0.470 & 23.874 & 134.749 \\
\hline
\end{tabular}


Effect of different concentration of $\mathbf{N}, \mathbf{P}$ and $K$ on number of fruits/ plant, avg. fruit weight and fruit yield/plant of capsicum in soilless media

The data on Number of fruit/plant after application of NPK in different treatment combinations was recorded and are presented in table 2. Critical analysis of data displayed in table clearly marked out the obvious difference among the treatments with respect to Number of fruit/plant. Statistically significant variation was recorded for Number of fruit/plant for different treatment combination of NPK. Maximum Number of fruit/plant (4.65) was recorded in treatment $\mathrm{T}_{5}$ (NPK $24.5 \mathrm{ml}$ ), followed by $\mathrm{T}_{3}$ (NPK 15.5 $\mathrm{ml})$ with (4.40), whereas minimum Number of fruit/plant (3.29), was observed in treatment $\mathrm{T}_{1}$ (NPK $5 \mathrm{ml}$ ). This might be attributed to enhanced photosynthesis, accumulation of carbohydrates and favourable effect on vegetative growth which increased the fruit set per plant and also increases the weight and size of fruit. This finding correlates the findings of Mohammed Dahiru Toungos (2017) and Ngupok et al., (2018) in Capsicum.

The data on Average fruit weight (g) after application of NPK in different treatment combinations was recorded and are presented in table 2. Critical analysis of data displayed in table clearly marked out the obvious difference among the treatments with respect to Average fruit weight. Statistically significant variation was recorded for Average fruit weight for different treatment combination of NPK. Maximum fruit weight $(269.30 \mathrm{~g})$ was recorded in treatment $\mathrm{T}_{5}$ (NPK $24.5 \mathrm{ml}$ ), followed by $\mathrm{T}_{3}$ (NPK $15.5 \mathrm{ml}$ ) with $(226.45 \mathrm{~g})$, whereas minimum fruit weight $(196.20 \mathrm{~g})$, was observed in treatment $\mathrm{T}_{1}$ (NPK $5 \mathrm{ml}$ ). This might be attributed to higher dose of $\mathrm{N}, \mathrm{P} \& \mathrm{~K}$ in treatment $\mathrm{T}_{5}$ enhanced photosynthesis, accumulation of carbohydrates and favorable effect on vegetative growth which increased the weight and size of fruit. This finding correlates the findings of Mohammed Dahiru Toungos (2017) and Ngupok et al., (2018) in Capsicum.

The data on Fruit yield/plant (g) after application of NPK in different treatment combinations was recorded and are presented in table 2. Critical analysis of data displayed in table clearly marked out the obvious difference among the treatments with respect to Fruit yield/plant. Statistically significant variation was recorded for Fruit yield/plant for different treatment combination of NPK. Maximum fruit yield $(1250.32 \mathrm{~g})$ was recorded in treatment $\mathrm{T}_{5}$ (NPK $24.5 \mathrm{ml}$ ), followed by $\mathrm{T}_{3}$ (NPK $15.5 \mathrm{ml}$ ) with $(995.51$ $\mathrm{g})$, whereas minimum fruit yield $(644.11 \mathrm{~g})$, was observed in treatment $\mathrm{T}_{1}$ (NPK $5 \mathrm{ml}$ ). This might be attributed to enhanced photosynthesis, accumulation of carbohydrates, development of cell wall and cell differentiations as they boost up overall vegetative growth, biological activity of the plants and retention of more flowers and fruits which increased number of fruits per plant and size of fruits besides increasing the yield. This finding correlates the findings of Mohammed Dahiru Toungos (2017) and Ngupok et al., (2018) in Capsicum.

From the present experimental findings, it is concluded that treatment $\mathrm{T}_{5}$ (NPK @ 24.5ml) was found best in terms of flowering and fruiting parameters followed by $T_{3}$ (NPK@15.5ml) where as minimum flowering and fruit yield was observed in treatment $\mathrm{T}_{1}$ (NPK@ $@$ ml).

\section{References}

Della Costa, L. and Gianquinto, G., (2002). Water Stress and Watertable Depth Influence Yield, Water Use Efficiency, 
and Nitrogen Recovery in Bell Pepper: Lysimeter Studies. Aust. J. Agric. Res., 53: 201-210.

Fatma Gungor and Ertan Yildirim (2013). Effect of different growing media on quality, growth and yield of pepper (Capsicum annuum 1.) under greenhouse conditions, Pak. J. Bot., 45(5): 16051608.

Khan, M. S., Roy, S. S. and Pall, K. K. (2010). Nitrogen and Phosphorus efficiency on the growth and yield attributes of capsicum. Acad. J. Plant Sci., 3: 71-78.

Mohammed Dahiru Toungos (2017) The effects of different levels of inorganic fertilizer (NPK 15:15:15,) on growth and yield of sweet pepper (capsicum annum) in mubi, Nigeria International Journal of Development Research., 07(06): 13120-13124.

Ngupok, O., Warade, S. D., Das, S., and Raghavan, M. (2018) Effect of NPK on quality parameters of capsicum (Capsicum annuum L. var. Grossum) under protected condition, International journal of chemical studies, 6(4):451453.

Schnitzler, W. H., Sharma, A. K., Gruda, N. S., and Heuberger, H. T. (2004). a lowtech hydroponic system for bell pepper (capsicum annuum 1.) production, international symposium on growing media and hydroponics, DOI:10.17660/Acta Hortic. 2004.644.3.

\section{How to cite this article:}

Mashetty Rakesh Kumar and Vijay Bahadur. 2020. Effect of Different Concentration of N, P and $\mathrm{K}$ on Yield at Capsicum (Capsicum annum L. Var. grossum) in Soilless Media. Int.J.Curr.Microbiol.App.Sci. 9(11): 122-127. doi: https://doi.org/10.20546/ijcmas.2020.911.014 